\title{
Annelated tricyclic thiophenes and their photophysical properties
}

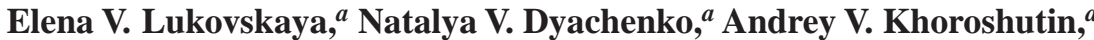 \\ Alla A. Bobyleva, ${ }^{a}$ Alexander V. Anisimov, ${ }^{a}$ Valentina A. Karnoukhova, ${ }^{b}$ \\ Gediminas Jonusauskas, ${ }^{c}$ Yurii V. Fedorov $^{b}$ and Olga A. Fedorova $* a, b$
}

\author{
a Department of Chemistry, M. V. Lomonosov Moscow State University, 119991 Moscow, Russian Federation. \\ Fax: +74959328568 \\ ${ }^{b}$ A. N. Nesmeyanov Institute of Organoelement Compounds, Russian Academy of Sciences, 119991 Moscow, \\ Russian Federation. E-mail: fedorova@ineos.ac.ru \\ c Centre de Physique Moléculaire Optique et Hertzienne, Université Bordeaux 1 - UMR CNRS 5798, \\ 33405 Talence, France. E-mail: gediminas.jonusauskas@u-bordeaux.fr
}

Photochemical oxidative cyclization of $3-[(E)-2-(3,4-d i-$ methoxyphenyl)vinyl]thiophene and its 15-crown-5-analogue (15-[(E)-2-(3-thienyl)vinyl]-2,3,5,6,8,9,11,12-octahydro-1,4, 7,10,13-benzopentaoxacyclopentadecine) affords the isomeric thiophene-containing fused aromatic compounds demonstrating photophysical properties different from those of initial styryl derivatives. $E$-Configuration of the initial styryl dye, 3-[(E)-2-(3,4-dimethoxyphenyl)vinyl] thiophene, has been proved by $\mathrm{X}$-ray analysis.
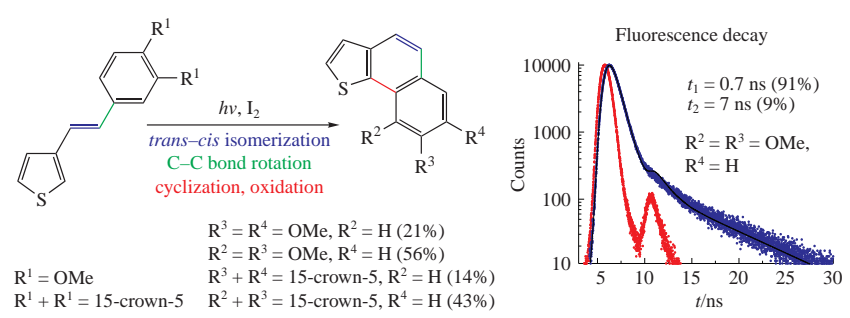

The photocyclization of stilbenes (1,2-diarylethenes) provides a convenient approach to novel planar polyaromatic compounds, and their heterocyclic analogues are of significant interest as prospective materials for electroluminescent devices, organic conductors and photovoltaic systems. ${ }^{1-3}$ As a rule, the existing methods for the synthesis of polycyclic heteroatomic compounds are multi-stage and laborious. ${ }^{4,5}$ Photochemical transformations of 1,2-di(het)arylethenes are now actively used for the synthesis of various classes of organic compounds that are difficult to access by alternative synthetic strategies. ${ }^{6-10}$ Specifically, three different pathways of the initially formed tricyclic cyclohexadiene-like structure are reported, namely, the reversed reaction, as in the case of photochromic switches, ${ }^{11,12}$ oxidation of cyclohexadiene to form tricyclic annelated aromatic scaffold, ${ }^{7,13,14}$ and $[1, n]$-hydrogen shift followed by the destruction of the periphery aromatic ring. ${ }^{15,16}$ The course of the reaction is governed by the preorganization of the double bond, heterocycle type, and reaction conditions, e.g. the acid concentration. ${ }^{17}$

Some examples of the photocyclization of 1,2-dithienyl- or 1-thienyl-2-arylethenes are known, ${ }^{18-21}$ however the diversity of the studied compounds is low for the assessment of the importance and the potential of this reaction. For instance, photocyclization of 1-thienyl-2-phenylethenes with varied substituents on the phenyl side is not studied in detail yet.

In view of our experience in the synthesis of thiophene-containing stilbenes, ${ }^{22}$ now we report the oxidative intramolecular photocyclization of 3-styrylthiophenes containing 3,4-dimethoxy (1) and 15-crown-5 ether (2) groups attached or annelated to its phenyl side (Scheme 1) ${ }^{\dagger}$ and photophysical characteristics of the

\footnotetext{
$\uparrow$ General procedure for the synthesis of $\mathbf{3 a}, \mathbf{b}$ and $\mathbf{4 a}, \mathbf{b}$. Photolysis was carried out by irradiating $0.1 \mathrm{M}$ cyclohexane solution of compounds $\mathbf{1}$ or $\mathbf{2}$ in the photoreactor with the light of a submerged mercury lamp during $30 \mathrm{~min}$. The solvent was removed, the residue was purified using column chromatography $\left(\mathrm{SiO}_{2}\right.$, ethyl acetate as an eluent).
}

obtained polycyclic products. The starting styryl derivatives were synthesized by the diethylphosphonate procedure ensuring the $E$ configuration of the double bond (see coupling constant for $E-\mathrm{C}=\mathrm{C}$ fragment in Figures S1, S5, Online Supplementary Materials, $\mathrm{X}$-ray crystallography $\ddagger$ data for compound $\mathbf{1}$ in Figure 1, and the

8,9-Dimethoxynaphtho[1,2-b]thiophene 3a: yield 56\%, mp 121-123 C. ${ }^{1} \mathrm{H}$ NMR (500 MHz, $\mathrm{CDCl}_{3}$ ) $\delta: 4.04$ (s, 3 H, Me), 4.13 (s, 3 H, Me), 7.29 (d, 1H, H-7, $\left.{ }^{3} J 8.9 \mathrm{~Hz}\right), 7.48$ (d, 1H, H-3, $\left.{ }^{3} J 5.4 \mathrm{~Hz}\right), 7.61$ (d, 1H, H-2, $\left.{ }^{3} J 5.4 \mathrm{~Hz}\right), 7.67$ (d, 1H, H-5, $\left.{ }^{3} J 8.6 \mathrm{~Hz}\right), 7.70\left(\mathrm{~d}, 1 \mathrm{H}, \mathrm{H}-6,{ }^{3} J 8.9 \mathrm{~Hz}\right), 7.74$ (d, $\left.1 \mathrm{H}, \mathrm{H}-4,{ }^{3} J 8.6 \mathrm{~Hz}\right) .{ }^{13} \mathrm{C}$ NMR (APT) $\left(125 \mathrm{MHz}, \mathrm{CDCl}_{3}\right) \delta: 56.73$ $(\mathrm{Me}), 60.36(\mathrm{Me}), 113.20\left(\mathrm{C}^{7}\right), 120.60\left(\mathrm{C}^{4}\right), 123.77\left(\mathrm{C}^{3}\right), 124.51\left(\mathrm{C}^{5}\right)$, $124.67\left(\mathrm{C}^{6}\right), 124.91 *\left(\mathrm{C}^{9 \mathrm{a}}\right), 126.91 *\left(\mathrm{C}^{5 \mathrm{a}}\right), 127.55\left(\mathrm{C}^{2}\right), 131.96^{*}\left(\mathrm{C}^{9 \mathrm{~b}}\right)$, $137.87 *\left(\mathrm{C}^{3 \mathrm{a}}\right), 142.52 *\left(\mathrm{C}^{9}\right), 149.50 *\left(\mathrm{C}^{8}\right) . \mathrm{MS}(\mathrm{ESI}), \mathrm{m} / \mathrm{z}(\%): 244[\mathrm{M}]^{+}$ (100). Found (\%): C, 68.87; H, 4.81. Calc. for $\mathrm{C}_{14} \mathrm{H}_{12} \mathrm{O}_{2} \mathrm{~S}(\%)$ : C, 68.83; $\mathrm{H}, 4.95$.

7,8-Dimethoxynaphtho[1,2-b]thiophene $\mathbf{3 b}$ (also observed in a mix-

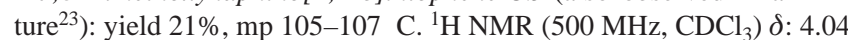
(s, 3 H, Me), 4.09 (s, 3 H, Me), 7.26 (s, 1H, H-6), 7.37 (s, 1H, H-9), 7.34 (d, 1H, Th, $\left.{ }^{3} J 5.3 \mathrm{~Hz}\right), 7.44\left(\mathrm{~d}, 1 \mathrm{H}, \mathrm{Th},{ }^{3} J 5.3 \mathrm{~Hz}\right), 7.62(\mathrm{~d}, 1 \mathrm{H}, \mathrm{H}-5$, $\left.{ }^{3} J 8.5 \mathrm{~Hz}\right), 7.72$ (d, $\left.1 \mathrm{H}, \mathrm{H}-4,{ }^{3} J 8.4 \mathrm{~Hz}\right) .{ }^{13} \mathrm{C} \mathrm{NMR}$ (APT) $(125 \mathrm{MHz}$, $\left.\mathrm{CDCl}_{3}\right) \delta$ : $55.92(\mathrm{Me}), 56.06(\mathrm{Me}), 103.15\left(\mathrm{C}^{9}\right), 107.86\left(\mathrm{C}^{6}\right), 120.28$ $\left(C^{4}\right), 123.83\left(C^{5}\right), 124.02\left(C^{3}\right), 124.20^{*}\left(C^{5 a}\right), 125.20\left(C^{2}\right), 125.96^{*}\left(C^{9 b}\right)$, $13630 *\left(\mathrm{C}^{9 \mathrm{a}}\right), 136.33^{*}\left(\mathrm{C}^{3 \mathrm{a}}\right), 148.94 *, 149.76^{*}\left(\mathrm{C}^{7,8}\right) . \mathrm{MS}(\mathrm{ESI}), \mathrm{m} / \mathrm{z}(\%)$ : $244[\mathrm{M}]^{+}(100)$. Found (\%): C, 68.92; H, 4.89. Calc. for $\mathrm{C}_{14} \mathrm{H}_{12} \mathrm{O}_{2} \mathrm{~S}(\%)$ : $\mathrm{C}, 68.83 ; \mathrm{H}, 4.95$.

2,3,5,6,8,9,11,12-Octahydrothieno[3',2' 7,8]naphtho[1,2-b][1,4,7, 10,13]pentaoxacyclopentadecine $4 \mathbf{a}$ : yield $43 \%$, mp 143-145 C. ${ }^{1} \mathrm{H}$ NMR $\left(400 \mathrm{MHz}, \mathrm{CDCl}_{3}\right) \delta: 3.79\left(\mathrm{~m}, 6 \mathrm{H}, \mathrm{CH}_{2} \mathrm{O}\right), 3.90\left(\mathrm{~m}, 2 \mathrm{H}, \mathrm{CH}_{2} \mathrm{O}\right), 3.99$ $\left(\mathrm{m}, 2 \mathrm{H}, \mathrm{CH}_{2} \mathrm{O}\right), 4.25\left(\mathrm{t}, 2 \mathrm{H}, \mathrm{CH}_{2} \mathrm{O},{ }^{3} \mathrm{~J} 6.1 \mathrm{~Hz}\right), 4.31\left(\mathrm{~m}, 2 \mathrm{H}, \mathrm{CH}_{2} \mathrm{O}\right), 4.49$ $\left(\mathrm{t}, 2 \mathrm{H}, \mathrm{CH}_{2} \mathrm{O},{ }^{3} \mathrm{~J} 6,0 \mathrm{~Hz}\right), 7.23\left(\mathrm{~d}, 1 \mathrm{H}, \mathrm{Ar},{ }^{3} \mathrm{~J} 8.8 \mathrm{~Hz}\right), 7.45(\mathrm{~d}, 1 \mathrm{H}, \mathrm{Th}$, $\left.{ }^{3} J 5.4 \mathrm{~Hz}\right), 7.58\left(\mathrm{~d}, 1 \mathrm{H}, \mathrm{Th},{ }^{3} J 5.4 \mathrm{~Hz}\right), 7.65$ (d, 1H, Ar, $\left.{ }^{3} J 8.3 \mathrm{~Hz}\right), 7.67$ (d, $\left.1 \mathrm{H}, \mathrm{Ar},{ }^{3} \mathrm{~J} 8.3 \mathrm{~Hz}\right), 7.72\left(\mathrm{~d}, 1 \mathrm{H}, \mathrm{Ar},{ }^{3} \mathrm{~J} 8.8 \mathrm{~Hz}\right) .{ }^{13} \mathrm{C}$ NMR (APT) $\left(100 \mathrm{MHz}, \mathrm{CDCl}_{3}\right) \delta: 68.83,69.66,70.33,70.38,70.43,70.97,71.04$ $72.71\left(\mathrm{CH}_{2}\right), 113.64,120.50,123.73,124.43,124.69,127.34\left(\mathrm{C}_{\text {tert }}\right)$, $125.12,126.91,131.87,137.81,141.61,148.62\left(\mathrm{C}_{\text {quat }}\right) . \mathrm{MS}(\mathrm{ESI}), \mathrm{m} / \mathrm{z}(\%)$ $374[\mathrm{M}]^{+}(100)$. Found (\%): C, 64.22; H, 5.99. Calc. for $\mathrm{C}_{20} \mathrm{H}_{22} \mathrm{O}_{5} \mathrm{~S}(\%)$ : C, 64.15; H, 5.92 . 
<smiles>[R]c1ccc(/C=C/c2ccsc2)cc1[R]</smiles>

12 (E-b)<smiles>[R]c1ccc(/C=C/c2ccsc2)cc1[R]</smiles><smiles>[R]c1ccc(/C=C/c2ccsc2)cc1[R]</smiles><smiles>[R]C1=C([R])C2C(=CC=C3C=CCCC32)C=C1</smiles><smiles>[R]c1ccc2ccc3ccsc3c2c1[R]</smiles>

$1,2(Z-a)$

$1,3 \mathrm{R}=\mathrm{OMe}$<smiles>[R4][R]#COCCOCCOCCOCCOC</smiles><smiles>[R]c1ccc(/C=C/c2ccsc2)cc1[R]</smiles>

$12(\mathrm{E}-\mathrm{d})$<smiles>[R]c1ccc(/C=C/c2ccsc2)cc1[R]</smiles>

$12(\mathrm{E}-\mathrm{c})$<smiles>[R]c1ccc(/C=C/c2ccsc2)cc1[R]</smiles>

$1,2(Z-c)$

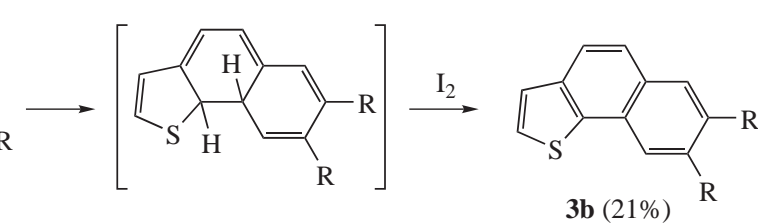

$\mathbf{4 b}(14 \%)$

Scheme 1

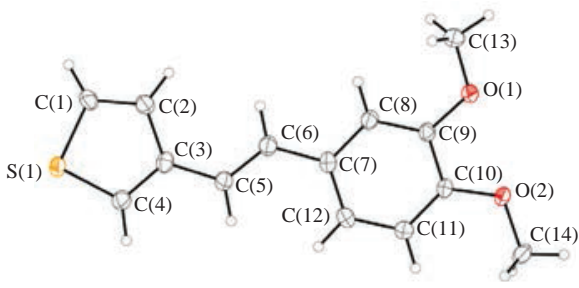

Figure 1 General view of molecule 1 in crystal in thermal ellipsoid representation for non-hydrogen atoms $(p=50 \%)$. The minor component of the disordered thiophene ring is omitted for clarity.

8,9,11,12,14,15,17,18-Octahydrothieno[2',3' 5,6]naphtho[2,3-b][1,4, 7,10,13]pentaoxacyclopentadecine $4 \mathbf{b}$ : yield 14\%, mp 138-140 C. ${ }^{1} \mathrm{H}$ NMR $\left(400 \mathrm{MHz}, \mathrm{CDCl}_{3}\right) \delta: 3.82\left(\mathrm{~m}, 8 \mathrm{H}, \mathrm{CH}_{2} \mathrm{O}\right), 4.00\left(\mathrm{~m}, 4 \mathrm{H}, \mathrm{CH}_{2} \mathrm{O}\right), 4.27$ (m, $\left.2 \mathrm{H}, \mathrm{CH}_{2} \mathrm{O}\right), 4.32\left(\mathrm{~m}, 2 \mathrm{H}, \mathrm{CH}_{2} \mathrm{O}\right), 7.23$ (s, 1H, H-6), 7.35 (s, 1H, H-20), 7.41 (d, 1H, Th, $\left.{ }^{3} J 5.3 \mathrm{~Hz}\right), 7.42\left(\mathrm{~d}, 1 \mathrm{H}, \mathrm{Th},{ }^{3} J 5.3 \mathrm{~Hz}\right), 7.58(\mathrm{~d}, 1 \mathrm{H}, \mathrm{Ar}$, $\left.{ }^{3} J 8.6 \mathrm{~Hz}\right), 7.70\left(\mathrm{~d}, 1 \mathrm{H}, \mathrm{Ar},{ }^{3} J 8.6 \mathrm{~Hz}\right) .{ }^{13} \mathrm{C} \mathrm{NMR}(\mathrm{APT})(100 \mathrm{MHz}$, $\left.\mathrm{CDCl}_{3}\right) \delta: 60.39,68.56,69.26,69.33,70.24,71.11,70.33,71.04\left(\mathrm{CH}_{2}\right)$, $104.83,109.77,120.26,123.85,124.05,125.16\left(\mathrm{C}_{\text {tert }}\right), 124.41,126.12$, 136.21, 136.28, 148.63, $149.50\left(\mathrm{C}_{\text {quat }}\right)$. MS (ESI), $m / z(\%): 374[\mathrm{M}]^{+}(100)$. Found (\%): C, 64.23; H, 5.89. Calc. for $\mathrm{C}_{20} \mathrm{H}_{22} \mathrm{O}_{5} \mathrm{~S}(\%)$ : C, 64.15; H, 5.92. * Crystal data for 1 . Crystals suitable for $\mathrm{X}$-ray diffraction were grown up by slow evaporation of solution in $\mathrm{CH}_{2} \mathrm{Cl}_{2}$. X-ray diffraction data were collected on a Bruker SMART APEX II diffractometer $[\lambda(\mathrm{MoK} \alpha)=$ $=0.71073 \AA$, $\omega$-scans, $2 \theta<61.53$ ]. Colorless crystals of $\mathrm{C}_{14} \mathrm{H}_{14} \mathrm{O}_{2} \mathrm{~S}$ $(M=246.31)$ at $120(2) \mathrm{K}$ are monoclinic, space group $P 2_{1} / c, a=$ $=9.0343(4), b=7.8258(4)$ and $c=17.5901(9) \AA, \beta=97.7296(10)$, $V=1232.33(10) \AA^{3}, Z=4, d_{\text {calc }}=1.328 \mathrm{~g} \mathrm{~cm}^{-3}, \mu=2.49 \mathrm{~cm}^{-1}, F(000)=520$. Frames were integrated using the Bruker SAINT software package ${ }^{24}$ by a narrow-frame algorithm. A semi-empirical absorption correction was applied with the $\mathrm{SADABS}^{25}$ program using the intensity data of the equivalent reflections. Intensities of 3785 independent reflections $\left(R_{\mathrm{int}}=\right.$ $=0.0270$ ) out of 12685 collected were used in structure solution and refinement. The structure was solved by direct methods and refined by the full-matrix least-squares technique against $F^{2}$ in anisotropic approximation. The positions of hydrogen atoms were calculated. Hydrogen atoms were refined in riding model with $U_{\text {iso }}(\mathrm{H})$ equal to $1.5 U_{\text {eq }}(\mathrm{C})$ and $1.2 U_{\text {eq }}(\mathrm{C})$ of the connected methyl carbon and other carbon atoms. Due to low contribution of the minor disordered component of the thiophene ring to the diffraction, the bond lengths and thermal parameters of this component were constrained to be the same as for the major component (SHELXL SAME and EADP instructions). The refinement converged to $R_{1}=0.0410$ [calculated for 3099 observed reflections with $I>2 \sigma(I)], w R_{2}=0.1118$ and $\mathrm{GOF}=1.048$. All calculations were performed with SHELX software package. ${ }^{26}$ For more details, see Online Supplementary Materials.

CCDC 1811313 contains the supplementary crystallographic data for this paper. These data can be obtained free of charge from The Cambridge Crystallographic Data Centre via http://www.ccdc.cam.ac.uk.
Table 1 Calculated values of ground state energies of $E$-1 conformers (see Scheme 1) and their fractions at $20 \mathrm{C}$.

\begin{tabular}{llll}
\hline$E-1$ conformer & $E / \mathrm{kcal} \mathrm{mol}^{-1}$ & Calculated fraction $(\%)$ & Product \\
\hline $\mathbf{a}$ & -9.467 & 51 & $\mathbf{3 a}$ \\
$\mathbf{b}$ & -9.263 & 21 & \\
\hline $\mathbf{c}$ & -8.929 & 10 & $\mathbf{3 b}$ \\
$\mathbf{d}$ & -9.197 & 18 & \\
\hline
\end{tabular}

spin system analysis). When irradiated, styrylthiophenes undergo $E-Z$-isomerization at the first stage (see Scheme 1), which can be evidenced by ${ }^{1} \mathrm{H}$ NMR at the early stages of the reaction (for instance, see Figure S1). The Z-forms are further cyclized and an unstable non-aromatic intermediate product is formed, 2-thienyl rather than 4-thienyl position being involved in the reaction. At the last step, this intermediate is oxidized as two hydrogen atoms are removed giving rise to an aromatic product. Each of the starting compounds, $\mathbf{1}$ and $\mathbf{2}$, yields two photoproducts, i.e. $\mathbf{3 a}, \mathbf{b}$ and $\mathbf{4 a}, \mathbf{b}$, respectively (see Scheme 1, Figures S2-S14).

Yields of products 3, 4 (see Scheme 1) are resonable enough; moreover, their formation occurs from readily available styryl derivatives upon mercury lamp irradiation at room temperature for $30 \mathrm{~min}$. Alternative synthetic pathways to similar fused compounds are laborious and multi-stage. Of particular interest is the fact that sterically hindered isomers $\mathbf{3 a}$ and $\mathbf{4 a}$ are formed in a higher yield. To rationalize such a preference, ground state energies of different conformers of the $E$-1a-d were calculated by MOPAC2016 program with PM7 Hamiltonian as well as their equilibrium amounts were calculated using the Boltzmann distribution model (Table 1).

Isomerization of $E$-isomers leads to the corresponding $Z$-isomers a-d (see Scheme 1, Table 1). Due to low reactivity of C-atom in the 4-position of the thiophene residue, the participation of $Z$-isomers $\mathbf{b}$ and $\mathbf{d}$ in the cyclization reaction can be disregarded. Thus, the cyclic products $\mathbf{3 a}$ and $\mathbf{4 a}$ can be formed from a and $\mathbf{c}$ conformers of $Z$-isomer. Because of the low activation barrier of the rotation around a single bond, conformers $\mathbf{b}$ and $\mathbf{c}$ can easily transform into $\mathbf{a}$ and $\mathbf{d}$, respectively. The ratio between fraction of $Z$-isomers $\mathbf{a}$ and $\mathbf{b}$ leading to product $\mathbf{3 a}$ and fraction of $Z$-isomers $\mathbf{c}$ and $\mathbf{d}$ giving product $\mathbf{4 a}$ is $72: 28$ (see Scheme 1). This ratio is close to that observed in synthesis $(2.7: 1)$. Thus, the calculations are in agreement with the experiment.

Table 2 shows the measured photochemical and photophysical characteristics (for details of measurements, see Online Supplementary Materials) of the styrylthiophenes 1, 2 and products 
Table 2 Photochemical and photophysical characteristics of styryl dyes 1, 2 and products of their photocyclization $\mathbf{3 a}, \mathbf{b}$ and $\mathbf{4 a}, \mathbf{b}$.

\begin{tabular}{|c|c|c|c|c|c|c|c|}
\hline Compound & $\lambda_{\mathrm{abs}} / \mathrm{nm}$ & $\lambda_{\mathrm{fl}} / \mathrm{nm}$ & $\Phi_{\mathrm{fl}}(\%)$ & Stokes shift $/ \mathrm{cm}^{-1}$ & $\begin{array}{l}\Phi_{E-Z}, \Phi_{Z-E}, \\
\Phi_{Z-\text { (cyclized products) }}(\%)\end{array}$ & $t_{1} / \mathrm{ns}(\%)$ & $t_{2} / \mathrm{ns}(\%)$ \\
\hline 1 & 318 & 356 & 7.1 & 3360 & $39,44,2.8$ & $0.41(100)$ & - \\
\hline $3 \mathbf{a}$ & 267 & 367 & 4.5 & 10200 & - & $0.71(91)$ & $6.74(9)$ \\
\hline $3 \mathbf{b}$ & 265 & 363 & 3.2 & 10200 & - & $0.28(50)$ & $1.10(50)$ \\
\hline 2 & 316 & 356 & 8.1 & 3560 & $44,49,4.5$ & $0.40(100)$ & - \\
\hline $4 \mathbf{a}$ & 266 & 365 & 2.8 & 10200 & - & $1.15(97)$ & $7.40(3)$ \\
\hline $4 b$ & 269 & 362 & 3.8 & 9550 & - & $0.67(100)$ & - \\
\hline
\end{tabular}

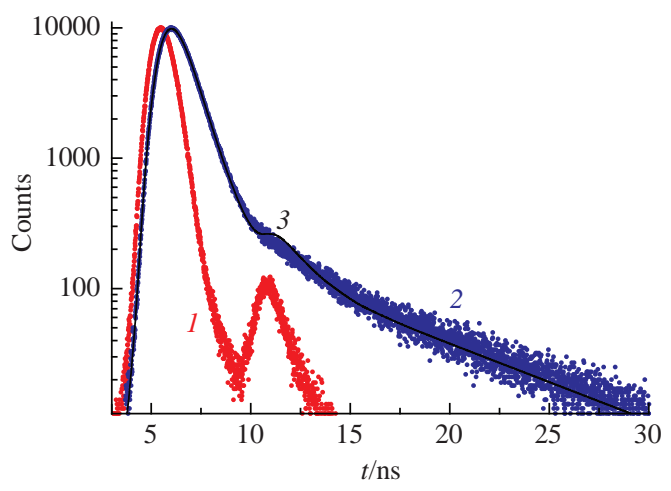

Figure 2 TCSPC histograms of (1) instrumental response, (2) fluorescence decay of $\mathbf{3 a}$ in cyclohexane and (3) the best biexponential fit of fluorescence decay in log scale. Excitation with $340 \mathrm{~nm}$ NanoLED.

of their photocyclization $\mathbf{3 a}, \mathbf{b}$ and $\mathbf{4 a}, \mathbf{b}$. The absorption and emission spectra are presented in Figures S15-S18. As an example, Figure 2 shows the fluorescence decay curve for $\mathbf{3 a}$ in cyclohexane, corresponding data for the rest compounds are presented in Figures S19-S24. As shown by measurements, the quantum yields of the direct and reverse $E-Z$-isomerization reactions of $\mathbf{1}$ and $\mathbf{2}$ are sufficiently high (Table 2, measurement of quantum yields is described in Online Supplementary Materials). The data given in Table 2 indicate the following changes in characteristics between styryl derivatives and cyclic ones: (i) shift of absorption bands of $\mathbf{3 a}, \mathbf{b}$ and $\mathbf{4 a}, \mathbf{b}$ to the short wavelength region as compared with those for $\mathbf{1}, \mathbf{2}$; (ii) significant increase of the Stokes shift (up to $100 \mathrm{~nm}$ ) in case of $\mathbf{3 a}, \mathbf{b}$ and $\mathbf{4 a}, \mathbf{b}$; (iii) decrease in the quantum yield of fluorescence going from $\mathbf{1}$ and $\mathbf{2}$ to $\mathbf{3 a}, \mathbf{b}$ and $\mathbf{4 a}, \mathbf{b}$; (iv) increase in the lifetime of the excited states for $\mathbf{3 a}, \mathbf{b}$ and $\mathbf{4 a}, \mathbf{b}$. Low quantum yields of fluorescence in combination with a large Stokes shift and longer lifetimes can indicate the possibility of intersystem crossing to triplet states in photoproducts.

In summary, we have proposed mild conditions for the photochemical cyclization of styrylthiophenes containing 3,4-dimethoxy and 15-crown-5 ether groups and conditions for the separation of the formed mixture of the photoproducts. Structures of isomeric cyclization products have been established and their photochemical and photophysical properties have been estimated.

This work was supported by the Russian Science Foundation (grant no. 17-73-30036). The equipment from Center of Collective Facilities of A. N. Nesmeyanov Institute of Organoelement Compounds was used.

\section{References}

1 D. Fichou, Handbook of Oligo- and Polythiophenes, Wiley-VCH, Weinheim, 1999.

2 C. Wang, H. Dong, W. Hu, Y. Liu and D. Zhu, Chem. Rev., 2012, 112, 2208.

3 E. V. Nosova, T. N. Moshkina, G. N. Lipunova, I. V. Baklanova, D. S. Kopchuk, P. A. Slepukhin and V. N. Charushin, Mendeleev Commun., 2018, 28, 14.

4 O. Baudoin, Acc. Chem. Res., 2017, 50, 1114.

5 X. Shi, J.-F. Soulé and H. Doucet, J. Org. Chem., 2017, 82, 3886.

6 Handbook of Synthetic Photochemistry, eds. A. Albini and M. Fagnoni, Wiley-VCH, Weinheim, 2010.

7 T. Bach and J. P. Hehn, Angew. Chem. Int. Ed., 2011, 50, 1000.

8 N. Hoffmann, Chem. Rev., 2008, 108, 1052.

9 K. B. Jørgensen, Molecules, 2010, 15, 4334.

10 F. D. Lewis, A. M. Bedell, R. E. Dykstra, J. E. Elbert, I. R. Gould and S. Farid, J. Am. Chem. Soc., 1990, 112, 8055.

11 H. Tian and S. Yang, Chem. Soc. Rev., 2004, 33, 85.

12 M. Irie, Phororeactive Materials for Ultrahigh-Density Optical Memory, Elsevier, Amsterdam, 1993.

13 O. Galangau, T. Nakashima, F. Maurel and T. Kawai, Chem. Eur. J., $2015,21,8471$.

14 A. G. Lvov, V. Z. Shirinian, A. V. Zakharov, M. M. Krayushkin, V. V. Kachala and I. V. Zavarzin, J. Org. Chem., 2015, 80, 11491.

15 T. Ho, J. Y. Wu and S. L. Wang, Angew. Chem. Int. Ed., 1999, 38, 2558.

16 A. G. Lvov and V. Z. Shirinyan, Chem. Heterocycl. Compd., 2016, 52, 658 (Khim. Geterotsikl. Soedin., 2016, 52, 658).

17 J.-H. Ho, T.-I. Ho and R. S. H. Liu, Org. Lett., 2001, 3, 409.

18 W. Carruthers and H. N. M. Stewart, Tetrahedron Lett., 1965, 301.

19 M. Irie and M. Mohri, J. Org. Chem., 1988, 53, 803.

20 K. Song, M.-L. Peng, M. Xu, L.-Z. Wu, L.-P. Zhang and C.-H. Tung, Tetrahedron Lett., 2002, 43, 6633.

21 M. L. Tedjamulia, J. G. Stuart, Y. Tominaga, R. N. Castle and M. L. Lee, J. Heterocycl. Chem., 1984, 21, 1215.

22 E. V. Lukovskaya, Yu. A. Sotnikova, A. A. Bobyleva, A. V. Anisimov, Yu. V. Fedorov, A. A. Moiseeva, A. V. Dolganov and O. A. Fedorova, Mendeleev Commun., 2016, 26, 202.

23 E. Sankar, P. Raju, J. Karunakan and A. K. Mohanakrishnan, J. Org. Chem., 2017, 82, 13583.

24 SAINT Data Reduction and Correction Program, Version 8.34A, Bruker AXS, Madison, WI, USA, 2013.

25 G. M. Sheldrick, SADABS-2014/5, Bruker/Siemens Area Detector Absorption Correction Program, Bruker AXS, Madison, WI, USA, 2014.

26 G. M. Sheldrick, Acta Crystallogr., 2008, A64, 112. 